\title{
Public Expenditure and Economic Growth in a Petroleum-Based Economy: Nigeria 1960-1992
}

\author{
Akpan H Ekpo \\ Department of Economics, University of Uyo, Nigeria
}

\begin{abstract}
The study analyses the contribution of government expenditure to the economic growth process in Nigeria over the period 1960-1992. The results indicate that public expenditures on transport, communication and agriculture crowd-in private investment, while public spending on manufacturing and construction crowd-out private investment. Also, expenditures on education and health have a positive influence on private sector investment. Government must continue to perceive the creation of an enabling environment, at the least, as its own contribution to the economic growth process.
\end{abstract}

JEL O4 1

\section{INTRODUCTION}

It is useful to analyse the impact of government size on economic performance and growth. At the theoretical level, some scholars argue that a larger government size may adversely affect efficiency and economic growth because: (i) government operations often take place inefficiently; (ii) the regulatory process places excessive burdens and costs on the economic system; and (iii) several of government's fiscal and monetary policies tend to distort economic incentives and hence reduce the productivity of the system (Ram, 1986). In this context, taxes and transfers distort market prices and thus reduce incentives for employment and investment. A critique of this position is that since taxes and transfers redistribute income from the rich, who tend to save a reasonably large fraction of their earnings, to the poor who spend all they can, government expenditures and taxes stimulate economic activity. The link here is between economic activity and the level as well as redistributive targeting of government revenues and outlays (Kalecki, 1971; Baran \& Sweezy, 1966). Other scholars have posited that a larger government size is a more powerful engine of growth. This contention is based on the belief that government reconciles conflicts between private and social interests. Also, the government seems to secure an increase in productive investment as well as providing a socially optimal direction for growth and development. 
Developing countries, especially sub-Saharan Africa, despite the attempt to curtail public expenditures in recent times, still contend that public expenditures do play an important role in the development process. In other words, public expenditures are still vital in creating the enabling environment for growth and development. Moreover, the present atmosphere of structural adjustment which implies, among other things, reduction in expenditure and/or expenditure switching, re-echoes the need to examine the role of public expenditure in the growth process.

There are many existing studies on the public expenditure-cum-growth nexus. However, most of these studies are cross-sectional in nature, and thus their conclusions may not be utilised in making general statements concerning individual countries. A country like Nigeria, given its size and huge public expenditures, may bias any cross-sectional study of sub-Saharan African countries as a group.

This paper examines the relationship(s) between public expenditures and economic growth via links with private investment in Nigeria. In addition, the paper shows how each type of expenditure profile influences the growth process in the country. The paper is organised as follows: Section 2 highlights the theoretical issues, while in section 3 I discuss components of public expenditure. An analysis of the results is presented in section 4 . Section 5 provides the conclusion and policy implications. This kind of analysis is significant in understanding the role of public expenditure in the economy's growth experience.

\section{REVIEW OF RELATED STUDIES/ THEORECTICAL ISSUES}

A simple Keynesian argument implies that high levels of government consumption are likely to increase employment and also profitability and investment via multiplier effects on aggregate demand. Others maintain that government consumption will "crowd-out" private investment by dampening any economic stimulus in the short-run and in the long-run by reduction in capital accumulation. Either way, the relationship is between levels of government spending and economic activity rather than total factor productivity.

There is no general agreement as to the exact relationship between government spending and economic growth. Scholars have arrived at different results. Using a sample of 96 developing countries, Landau (1983) inferred that big government, measured by the share of government consumption expenditures in gross national product (GNP) or gross domestic product (GDP), reduced the growth of per capita income. Landau (1986) re-affirmed these earlier findings by examining other sets of variables influencing economic growth; these variables included per capita 
income, the structure of production, population features and global economic conditions.

Some researchers have concluded that a larger government revenue in GNP enhances economic growth mostly in poorer developing countries (Rubinson, 1977). Ram (1986) and Grossman (1988) have found positive relationships between government spending and economic growth. The work of Grossman (1988) utilised a simultaneous equation model making allowance for a non-linear relationship between growth in government and total economic growth, while that of Ram (1986) was based on a production function approach.

In a recent study, Diamond (1989) used a sample of 42 developing countries and discovered that social expenditure does exhibit a significant impact on growth in the short-run while infrastructural expenditures showed little influence. In addition, he found that capital expenditures exert a negative influence on the growth process. Interestingly, Diamond's work confirms the significance of the growth of exports to the overall growth rates.

It is important to note that most of the works referred to above were based on cross-country analysis. A country like Nigeria, though a developing one, may be quite different when compared to other sub-Saharan African economies, for example, she may not "suffer" from oil shocks. Moreover, it is necessary to decompose the components of government spending not only into the usual capital and recurrent but also into social (education, health, welfare), productive, defence, etc. categories, if any empirical study is to make sense. Many studies have concentrated on the use of capital expenditures because of its influence on technological change.

At the analytical level, there is also some controversy regarding the influence of government expenditures on economic growth. It is agreed by some scholars that all government spending whether it is current or capital has a retarding effect on economic growth. This perception is based on the contention that government investment with its inherently centralised decision-making, absence of profit motive and lack of competition, is inefficient when compared with the private sector. Assuming the lower productivity of government investments, "any increase in government expenditure, by increasing the share of productive resources used by the government, would slow economic growth in the economy as a whole and may impede the accumulation of human and physical capital and the pace of innovation in the private sector" (Diamond, 1989: 5). This conclusion needs to be modified so as to take into account the fraction of government purchases of privately produced output in total expenditure increases, relative to government own-produced services. 
The controversy over the growth effects of government expenditures is partly due to our incomplete understanding of the growth process and the determinants of economic expansion. Consequently, the following modified Denison-style growth accounting methodology (Denison, 1962) will assist our analysis:

$$
\begin{aligned}
& y=a+b+e m+c k+(1-c) h \\
& \text { where } \\
& y=\text { growth rate of real output; } \\
& a=\text { change in the efficacy of resource use of; } \\
& b=\text { rate of technical change; } \\
& k=\text { physical capital growth; } \\
& h=\text { human capital; and } \\
& m=\text { growth of intermediate imports. }
\end{aligned}
$$

In equation (1), the growth of real output is decomposed into four sources. An analysis of equation (1) illuminates the perceived significance of govemment expenditures. Government capital spending influences physical capital. The effect will be positive if there is a net increase in physical capital. However, if government tax and revenue-raising measures as well as the financing of government expenditures cause the investible surplus of the private sector to decrease, then an increase in government capital expenditure could slow down economic growth. Government expenditure also affects human capital formation. The public sector invests in education and health in order to enhance the labour force's productivity. In the context of human capital formation, it is important to analyse the contribution of government current expenditure even though this aspect is not explicit in equation (1). It would be important to include current and capital expenditures in the social sector as explanatory variables in accounting for the growth of human capital. There are recent studies that have stressed the importance of human capital in the growth process (Otani \& Villanueva, 1989 \& 1990). These studies seem to suggest a positive relationship between human capital and long-run economic growth.

Another likely influence of capital expenditures on the growth rate arises from its link to technological change. In developed countries, government expenditure on research and development has had spillover effects on the wider economy. Developing countries like Nigeria have also gained from research and development expenditures on, for example, new agricultural techniques. It is only the government that has invested huge sums of money on seed varieties and other aspects of the green revolution programme. It may be difficult to examine such an effect empirically, especially since the bulk of expenditure may fall under recurrent items. 
The influence of the efficacy of the efficient use of resources on the growth rate is not easy to quantify. The conventional reason for government intervention is the breakdown of the market system, implying a case of underinvestment in public goods. These public goods may be seen as essential inputs in the private sector production process. For example, internal security and public order is a necessary condition for a healthy investment environment, and could indeed be perceived as one of the variables influencing the "enabling environment" thesis.

Then there is the issue of intermediate imports which are now viewed as a factor of production especially when an economy is constrained by foreign exchange. A more generalised growth model will incorporate exports as an engine of growth. From the production side, increased output of export goods will result in the development of infrastructure, transport and communication system - which in turn enhances the production of other goods and services (Goldstein \& Khan, 1982; Bardhan \& Lewis, 1970; Chen, 1979; Khand, 1987). On the demand side, "an increase in income results directly from a rise in demand for a wide range of products, including non-tradeables. These demand-pressures are reflected in an expansion in domestic supply and therefore, involve investment in facilities providing such products" (Khan \& Villanueva, 1991: 8).

There are significant links between public expenditure and private investment. Those that stress the financing side of expenditure draw attention to the private investment crowding-out effects of government expenditure. When it is assumed that private investment has higher productivity than public investment, a negative effect on gowth is deduced. Those that emphasize the expenditure side show the private investment crowd-in effects of public expenditure, since these will tend to enhance the absorptive capacity of the economy and the profitability of private investment.

Some scholars have hypothesized that the response of private investors depended on the stage of the business cycle, the availability of financing and the level of public investment. While the effect of the stage of the cycle appeared uncertain, that of available finance seemed less ambiguous.

Indeed, because the total amount of financing is limited and the price mechanism is not allowed to operate smoothly, it would seem legitimate to hypothesize that the private investor in a developing country is restricted by the level of available bank financing (Blejer \& Khan, 1984: 386).

However, the nature of capital markets in developing economies limits the financing of private investment to the use of retained profits, bank credit and foreign borrowing. For a country like Nigeria, the liberalisation of interest rates has further increased the cost of investible funds. 
There is no doubt that public sector investment can crowd-out private investment if it uses scarce physical and financial resources that would otherwise be available to private investors. Alternatively, the same scenario will occur if the public sector produces marketable output that competes with private output. In addition, the financing of public sector investment either through taxes, debt issuance or inflation will reduce the resources available to the private sector and therefore dampen private sector activities (Chibber \& Dailami, 1990).

Some of the issues discussed above can be summarised in the following equations:

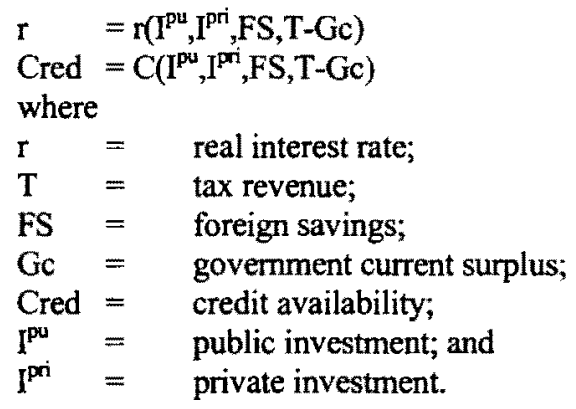

From equations (1) and (2), it is assumed that both public and private investment will exert positive influence on the real interest rate, while foreign saving and government current surplus should be inversely related to the real interest rate. In an economy where credit availability is through credit rationing, private and public investment will be $a$ priori negatively related to credit availability. Foreign savings and government current surplus will have a positive relationship with credit availability. The estimated results of some variant of the above equations are presented in section 4 below.

Blejer and Khan (1984) maintain that public investment which has some bearing on infrastructure and the provision of public goods, can be complementary to private investment. They show for a group of developing countries that longerterm infrastructural expenditures, rather than short-term public investment, positively induce private investment. The other types of government investment may be substitutes for private capital.

In recent times, an attempt has been made to separate the independent effects of private and public sector investment on growth. Khan and Reinhart (1990) tested empirically the relative productivity of private and public investment for a crosssection of 24 developing countries. Their results confirm the notion that private investment has a larger direct effect on growth than public investment. They also 
re-affirm the indirect effects of public investment on growth through raising profitability of private investment and the absorption capacity of the economy.

Wagner's law which connotes that as income rises, the demand for government services increases more than proportionately, seems to explain the income effects caused by the increasing relative price of government production. This is so because of the technological requirements of industrialisation and the attendant urbanisation.

\section{COMPONENTS OF PUBLIC EXPENDITURE}

Table 1 below summarizes the growth rate of selected components of expenditure for the periods 1960-65, 1970-75, 1976-80, 1981-85, and 1986-1992. These periods have significance and represent important episodes in the Nigerian economy. The 1960-65 period attempts to capture not only the beginning of the independence era but also the commodity export boom situation at the time. The years 1970-75 reflect the period of the windfall from oil; 1976-80 also incorporates part of the oil boom and the first austerity measures. The period 198185 was characterised by extensive austerity measures and various stabilisation packages. The structural adjustment period is represented from 1986 to 1992.

Capital expenditure grew negatively by 0.5 per cent during the period 1960-65. Its lowest growth was in 1981-85 - the era of austerity. It experienced the highest growth rate of $26.7 \%$ during the period characterised by the windfall from oil (1970-75). In fact, virtually all items in Table 1 recorded very high growth rates during this period. Education, capital and current, grew by $143.9 \%$ and $102.2 \%$ respectively. Agriculture also experienced growth rates of $83.1 \%$ and $43.7 \%$ for capital and current expenditures during 1970-75. Transport and communication grew by $68.5 \%$ and $30.7 \%$ respectively for the same period. These significant jumps partially confirm the oil boom hypothesis.

It is interesting to note that social services suffered during the independence and austerity periods.Education (capital and current) grew negatively by $6.9 \%$ and $2.0 \%$ respectively.

One might have thought that the period after independence would have witnessed massive investment in the development of human capital. Perhaps, the figures presented still reflected the initiatives left behind by the colonialists. It can be argued that the massive expenditure on education by the independence government had its impact later in the economy. 
Health and education seemed to have fared poorly during 1981-85 in terms of capital expenditures. This is understandable since during crisis, it may be anticlassical thinking for government to invest in or start new projects, especially as the various austerity measures and stabilisation policy canvassed a lesser role for government.

Another significant development is the growth of defence expenditure. Its capital component grew by $4.8 \%$ during $1960-65$; it increased to $52.1 \%$ during the windfall from oil, grew negatively by $17.0 \%$ during the period of austerity and showed tremendous growth in the period of adjustment $(38.7 \%)$.

It is noticeable that some form of expenditure switching in favour of social services took place during structural adjustment. It is generally argued that during adjustment curtailment of expenditures through reduction or elimination of subventions on social services affect the poor, and that what government should do is to switch expenditures in favour of some basic social services in order to at least allow some minimum access by vulnerable groups. During adjustment in Nigeria, the evidence in Table 1 seems to suggest that health, education, housing and economic services like agriculture did not experience drastic cuts by government.

Gross domestic product in real terms grew by $4.4 \%$ and $5.7 \%$ during the periods 1960-65 and 1970-75 respectively. During adjustment, GDP recorded a growth rate of $1.5 \%$ improving from the previous year's negative growth of $0.6 \%$. The marginal growth of $1.5 \%$ between $1986-90$ may be due to the implementation of structural adjustment policy.

Table 1 Nigeria: Compound Growth Rate of Selected Components of Expenditure and Gross Domestic Product (GDP), 1960-92 (\%)

\begin{tabular}{|l|c|c|c|c|c|}
\hline Item & $\mathbf{1 9 6 0 - 6 5}$ & $\mathbf{1 9 7 0 - 7 5}$ & $\mathbf{1 9 7 6 - 8 0}$ & $\mathbf{1 9 8 1 - 8 5}$ & $\mathbf{1 9 8 6 - 9 2}$ \\
\hline Cap. Exp. & -.5 & 26.7 & 1.2 & 0.6 & 3.3 \\
\hline Education & -6.9 & 143.9 & 6.6 & -10.3 & 3.8 \\
\hline Health & 15.3 & 17.9 & 27.1 & -28.0 & 20.8 \\
\hline Housing & - & - & 33.0 & -4.5 & 15.8 \\
\hline Agriculture & 7.0 & 83.1 & 26.2 & -33.3 & 21.8 \\
\hline Manufact. & 11.0 & 26.3 & 143.4 & -21.8 & 21.5 \\
\hline Transport* & 22.8 & 68.5 & 12.2 & -29.6 & 3.0 \\
\hline Defence & 4.8 & 52.1 & 10.1 & -17.0 & 38.7 \\
\hline Curr. Exp. & 4.2 & 5.2 & -2.2 & -1.8 & 11.2 \\
\hline Education & -2.0 & 102.2 & -0.5 & -0.4 & 21.6 \\
\hline Agriculture & 10.8 & 43.7 & 24.8 & 5.1 & 34.5 \\
\hline Health & 8.9 & 3.2 & 15.6 & 8.1 & 22.0 \\
\hline
\end{tabular}


Table 1 continued

\begin{tabular}{|l|c|c|c|c|c|}
\hline Item & $1960-65$ & $1970-75$ & $1976-80$ & $1981-85$ & $1986-92$ \\
\hline Manufac. & 19.2 & 26.8 & 26.3 & -7.7 & 19.7 \\
\hline Transport* & 2.4 & 30.7 & 25.0 & -0.2 & 20.4 \\
\hline Defence & 25.6 & 22.8 & 25.6 & 1.6 & 15.2 \\
\hline GDP & 4.4 & 5.7 & 1.6 & -0.6 & $1.5^{* *}$ \\
\hline
\end{tabular}

Source: Computed by the author based on data from:

(i) Central Bank of Nigeria: Economic and Financial Review, various issues, Lagos.

(ii) Federal Office of Statistics, Abstract of Statistics, various issues, Lagos.

(iii) Federal Ministry of Education, Lagos.

(iv) Federal Ministry of Finance, Lagos.

Notes:

* includes communication;

** period 1986-90; Manufacturing includes mining and quarring and construction.

\section{ANALYSIS OF THE RESULTS}

The analysis here differs from previous efforts (Blejer \& Khan, 1984) in that apart from being country-specific (non-cross sectional), it decomposes public sector investments into specific categories. Furthermore, our efforts capture the periods of stabilization and structural adjustment.

The regression results using OLS with annual data for 1960-1990 for the public expenditure-cum-private investment nexus are presented below:

$$
\begin{aligned}
& \mathrm{Ip}=.001+1.609 \mathrm{dy}+1.37 \mathrm{FS} *+.080 \mathrm{PE}-.110 \mathrm{PE} \\
& \begin{array}{llll}
(.166) & (.458) \quad(7.40) \quad(.266) & (-.826)
\end{array} \\
& \mathrm{R} 2=.96 ; \mathrm{F} 5,25=131.12 \\
& \text { Ip }=22.32+10.25 \text { Cafr }^{* *}+2.84 \text { Cagr }-1.20 \text { Cam } \\
& \begin{array}{llll}
(1.55) \quad(5.86) \quad(.90) \quad(-.413)
\end{array} \\
& -.001 \mathrm{dy}-.172 \mathrm{FS} \\
& (-.009) \quad(.994)
\end{aligned}
$$

$\mathrm{R} 2=.88 ; \mathrm{F} 6,24=29.81$.

$$
\mathrm{Ip}=31.31^{*}+21.375 \mathrm{Cae}^{* *}+31.64 \mathrm{Cah}^{* *}+.012 \mathrm{dy}-.534 \mathrm{FS}^{* *}
$$




$$
\begin{aligned}
& \begin{array}{llll}
(1.86) \quad(5.143) & (2.175) \quad(.078) \quad(-3.049)
\end{array} \\
& \mathrm{R} 2=.82 ; \quad \mathrm{F} 5,25=22.8 \\
& \text { Ip }=46.79+78.66 \mathrm{Cuh}^{*}+15.21 \mathrm{Cue}^{*}+53.72 \mathrm{Cum}-42.48 \mathrm{Cufr}^{* *} \\
& \begin{array}{llll}
(1.594)(1.807) \quad(1.738) \quad(2.257) \quad(-3.415)
\end{array} \\
& +59.19 \mathrm{Cugr}+.069 \mathrm{dy}+.104 \mathrm{FS} \\
& \begin{array}{lll}
(.374) \quad(.287) \quad(.153)
\end{array} \\
& \mathrm{R} 2=.65 ; \quad \mathrm{F} 8,25=5.04 \text {. } \\
& \mathrm{Ip}=2.95+.052 \mathrm{dy}-73.73 \mathrm{PE}+73.481 \mathrm{PE}^{*}+.985 \mathrm{Ip}-1^{* * 1} \\
& +.047 \mathrm{FS} \\
& \begin{array}{llll}
(.623) \quad(.563) \quad(1.98) \quad(9.62)
\end{array} \\
& \text { (.636) } \\
& \mathrm{R} 2=.95 ; \quad \mathrm{F} 6,24=85,71 . \\
& \begin{array}{c}
\mathrm{Ip}= \\
(1.038)(6.687) \\
(.450)(1.776)(.332)(.222)
\end{array} \\
& \mathrm{R} 2=.95 ; \quad \mathrm{F} 6,24=85.72
\end{aligned}
$$

Notes:

* significant at the $10 \%$ level;

** significant at the 5\% level;

$t$ scores are in parenthesis.

\section{Definition of Variables:}

Ip = Gross private fixed capital formation;

y = Gross domestic product(GDP);

$\mathrm{PE}=$ Public sector investment;

Cafr $=$ Capital expenditure on transport and communications;

Cagr $=$ Capital expenditure on agriculture;

Cam $=$ Capital expenditure on construction and manufacturing;

$\mathrm{Cae}=$ Capital expenditure on education;

$\mathrm{Cah}=$ Capital expenditure on health;

Cuh $=$ Current expenditure on health;

Cue $=$ Current expenditure on education;

Cum $=$ Current expenditure on construction and manufacturing;

Cufr $=$ Current expenditure on transport and communications;

Cugr $=$ Current expenditure on agriculture;

$\mathrm{dy}=$ Accelerator; 
FS $=$ Foreign saving;

$\mathrm{Gc}=$ Government current surplus;

Cuxp $=$ Total current expenditure;

All variables are in real terms.

Equations (4) - (6) provide interesting results. The change in GDP (accelerator) exerts positive influence on private investment as expected, though it is not statistically significant. The change in public investment has a positive impact on private investment while the level of public investment crowds-out private investment. Foreign saving has the expected sign implying that increases in foreign savings will bring in private investment. Foreign saving is also statistically significant at the $5 \%$ level, two tail test. The coefficient of determination R2 is .96 which reflects the fact that the explanatory variables to a very large extent explain the variation in private investment. That changes in public investment crowds-in private investment, is not surprising given the huge public sector capital expenditures in the economy. Following the windfall from oil, government took over the commanding heights of the economy and participated actively in the ownership of companies.

In equation (5), capital expenditures on transport and communications as well as agriculture crowd-in private investment. The transport and communications coefficient is statistically significant. In Nigeria, government has invested massively in transport and communications though these results say nothing about the quality of services. Construction and manufacturing crowd-out private investment. The result indicates that the private sector is better placed to invest in construction and manufacturing if allowed to do so by government. It is possible that manufacturing exceeded construction especially in the $1970 \mathrm{~s}$ when government embarked on various heavy industrial projects. Furthermore, defence expenditures may have captured most of the construction activities in the economy, epitomised by the building of barracks for the expansion of the armed forces. This scenario is suggested by the positive effect of defence spending on private investment (see Ekpo, 1995 for details). Capital expenditure on agriculture, though not statistically significant, influences investment positively. It follows that government expenditures on irrigation, extension services, etc. can stimulate private initiative. It is surprising that both the accelerator and foreign savings do not have the expected signs.

Capital expenditures on education and health have positive impact on private investment which invariably enhances growth; both coefficients are statistically significant. There is no question that private investment benefits from the stock of skilled manpower already trained by government. The Nigerian government after the oil boom embarked on massive training of manpower. Scholarships were provided at all levels of education. Schools (primary, secondary, polytechnics, 
universities, etc.) were constructed and equipped by govemment. The private sector definitely taps from such public sector investment.

In Nigeria, health expenditures are provided by the federal, state and local governments. More than 50 per cent of public health expenditures occur at the state level, 15-23 per cent at the local level, and about 33 per cent at the federal level. There were huge investments in health care infrastructure following the oil boom of the 1970s; government invested in the construction of many hospitals, the buying of medical equipment and drugs as well as the training of health-care personnel. It is thus apparent that education and health contribute indirectly to economic growth via its crowding-in effects on private investment.

Current expenditures also contribute to the growth process via private investment. Equation (7) shows that current expenditures on health, education, agriculture, construction and manufacturing crowd-in private investment. On the other hand, current spending on transport and communication crowd-out private investment. In addition, changes in both income and foreign savings have positive influence on private investment though they are not statistically significant.

The result in equation (8) indicates that private investment (with a one-year lag) enhances present private investment and it is statistically significant. It is interesting that with the lagged private investment, the level of public sector investment crowds-out private investment while foreign saving and changes in output crowd-in private investment. In equation (9), government current surplus stimulates private investment. In fact, equations (8) and (9) confirm the expected results; all the variables have the expected signs with satisfactory test statistics. It must, however, be noted that only past investment and change in public sector investments are statistically significant, at the $5 \%$ and $10 \%$ levels of significance respectively.

\section{CONCLUSION}

I have analysed the contribution of government expenditures on the growth process in Nigeria. The links between private investment and public expenditures were also investigated.

There is no doubt that government expenditures on infrastructure complement and even stimulate private initiatives. Regression results confirm that public sector investments, particularly those on transport and communications, and agriculture have positive impact on private investment. In aggregate terms, public sector investment crowds-in private investments while its changes crowds-out private investment. In terms of growth, private investment appears more efficient than 
public sector investment. It was also shown that private investment benefits from government investment in human capital formation and the provision of health care. Capital and current expenditures on education and health did not only have the correct signs but the capital components were statistically significant. In most of the regression results, foreign saving was positively correlated to private investment.

It is clear that government in Nigeria must continue to create the enabling environment by investing in large-scale irrigation projects, transport and communications as well as providing other utilities like electricity and water. The quality of government investment is important for ensuring the efficiency of the private sector.

While this study confirms previous efforts on the positive contribution of infrastructural expenditures to the growth process, it also makes the point that it is important also to decompose the infrastructural aspects in order to explain better the government's role in the growth process.

\section{ENDNOTE}

I wish to acknowledge the African Economic Research Consortium (AERC), based in Nairobi, Kenya for financing the study on which this paper is based. The contributions of the AERC Technical Committee, resource persons, and workshop participants (group B) are appreciated. I also thank my colleagues at the Joint Facility for Electives (JFE), Karen, Nairobi, August 14-October 4, 1996 for useful comments. However, the usual caveat applies.

\section{REFERENCES}

1 ANDERSON, D. (1987) "Economic Growth and the Returns to Investment," World Bank Discussion Paper No. 12.

2 ARIYO, A. \& RAHEEM, M.I. (1990) "Deficit Financing and Economic Development: Empirical Perspectives from Nigeria", Final Report, African Economic Research Consortium, Nairobi, Kenya.

3 BARAN, P.A. \& SWEEZY, P.M. (1966) Monopoly Capital, Penguin Books, Harmondsworth.

4 BARDHAM, P. \& LEWIS, S. (1970) "Models of Growth with Imported Inputs." Economica, 37: 373-85.

5 BARRO, R.J. \& LEE, J. (1993) "Losers and Winners in Economic Growth." Annual Bank Conference on Development Economics, May: 3-4, Washington DC. 
6 BECK, M. (1979) "Public Sector Growth: A Real Perspective", Public Finance, 36(3).

7 BIERJER, M.I. \& KHAN, M.S. (1984) "Government Policy and Private Investment in Developing Countries", IMF Staff Papers, 31: 379-403.

8 CHEN, E.K.Y. (1979) Hyper-Growth in Asian Economies: A Comparative Study of Hong Kong, Japan, Korea, Singapore, and Taiwan, Holmes and Meier, New York.

9 CHIBBER A. \& DALLAMI, M. (1990) "Fiscal Policy and Private Investment in Developing Countries: Recent Evidence on Key Selected Issues", Recherche Economique, September.

10 DENISON, E.F. (1962) The Sources of Economic Growth in the United States, Committee for Economic Development, New York.

11 DIAMOND, J. (1989) "Government Expenditure and Economic Growth: An Empirical Investigation", IMF Working Paper, 89/45, May.

12 EKPO, A.H. (1987) "Capital Formation in Selected West African Countries: Theory and Empirical Evidence", Analsis Economico, 2.1: 35-47.

13 EKPO, A.H. \& NDEBBIO, J. (1991) "Fiscal Operations in a Depressed Economy: Nigeria, 1960-90," Final Report, AERC, Nairobi, Kenya.

14 EKPO, A.H. (1992) "Economic Development Under Structural Adjustment: Evidence From Selected West African Countries," Journal of Social Development in Africa, 7(1).

15 EKPO, A.H. (1992) "Unemployment and Inflation during Structural Adjustment: The Nigerian Experience", Eastern African Economic Review, 8(2): 102-13.

16 EKPO, A.H. (1994) "Fiscal Federalism: Nigeria's Post-Independence Experience, 1960-90", World Development, 22(8): 1129-46.

17 ELBADAWI, I.A. \& NDULU, B. (1994) "Long-term Development And Sustainable Growth In Sub-Saharan Africa", paper presented at the SAREC International Colloquim, Stockholm, March.

18 EASTERLY, W. \& LEVINE, R (1993) "Is Africa Different?" Evidence from Growth Regressions, Processed. World Bank.

19 GOLDSTEIN, M. \& KHAN, M. (1982) "The Effects of Slowdown in Industrial Countries on Growth in Non-oil Developing Countries", IMF Occasional Paper 12, Washington, DC.

20 GROSSMAN, P.J. (1988) "Government and Economic Growth: A Nonlinear Relationship," Public Choice, 56(2): 193-200.

21 GUPTA, S.P. (1986) "Public Expenditure and Economic Development: A Cross-section Study," Finanzarchiv, June, 24- 41.

22 GARFINKEL, M.R. (1990) "The Economic Consequences of Reducing Military Spending", Review, Federal Reserve Bank of St. Louis, 72(6).

23 HELLER, P \& DIAMOND, J. (1990). "International Comparisons of Government Expenditure Revisited: The Developing Countries, 1975-86", IMF Occasional Paper 69, Washington DC. 
24 KALECHI, M. (1971) Selected Essays on the Dynamics of the Capitalist Economy, Cambridge, England.

25 KHAN, M.S. \& MONTIEL, P.J. (1988) "Growth-Oriented Adjustment Programs: A Conceptual Framework", IMF Working Paper 88/64, Washington DC.

26 KHAN, M.S \& REOMJAR, C. (1990) "Private Investment and Economic Growth in Developing Countries", World Development, 18: 19-27.

27 KHAN, M.S. \& VILLANUEVA, D. (1991) "Macroeconomic Policies and Long-term Growth", AERC Special Paper 13, Nairobi, Kenya.

28 KHAN, M.S. \& KUMAR, M. (1993) "Public and Private Investment and the Convergence of Per Capita Incomes in Developing Countries", IMF Working Paper, Washington DC.

29 KHAND, C. (1987) "Export-led Economic Growth: The Case of Technology Transfer", The Economic Studies Quarterly, 38: 131-47.

30 KUZNETS, S. (1966) Modern Economic Growth: Rate, Structure, and Spread, New Haven, Yale University Press.

31 LANDAU, D.L. (1983) "Govermment Expenditure and Economic Growth: A Cross Country Study", Southern Economic Journal, 49(3): 783-92.

32 LANDAU, D.L. (1985) "Government Expenditure and Economic Growth in the Developed Countries: 1952-76", Public Choice, 47(3): 459-77.

33 LANDAU, D.L. (1986) "Government Expenditure and Economic Growth in Less Developed Countries: An Empirical Study for 1960-80", Economic Development and Cultural Change, 35: 35-75.

34 LEWIS, W.A. (1955) The Theory of Economic Growth, London, Allen and Unwin.

35 LINDAUER, D.L. \& VALENCHIK, A.D. (1992) "Government Spending in Developing Countries: Trends, Causes and Consequencies", The World Bank Research Observer No.1, 7: 59-78.

36 MUELLER, D.C. (1987) "The Growth of Government: A Public Choice Perspectives", IMF Staff Papers 34(1): 115-49, Washington DC.

37 OTANI, I.O. \& VILLANEUVA, D. (1988) "Determinants of Long-term Growth Performance in Developing Countries", IMF Working Paper 88/97, Washington DC.

38 OTANI, I.O. \& VILLANEUVA, D. (1990) "Long-Term Growth in Developing Countries and its Determinants: An Empirical Analysis." World Development, 18: 769-83.

39 NDULU, B. (1990) "Growth and Adjustment in sub-Saharan Africa", World Bank Conference, Nairobi, Kenya.

40 RAM, R (1986) "Government Size and Economic Growth: A New Framework and Some Evidence from Cross-sectional and Time-series Data", American Economic Review, 76(1): 191-203. 
41 RUBINSON, R. (1977) "Dependence, Government Revenue, and Economic Growth, 1955-1970", Studies in Comparative International Development, XII(2): 3-28.

42 SOLOW, R.M. (1988) "Growth Theory and After", American Economic Review, 78(3): 307-17.

43 TAIT, A.A. \& MUELLER, P. (1982) "International Comparisons of Government Expenditures", IMF Occasional Paper 10, Washington. DC.

44 TAYLOR, L. (1983) Structuralist Macroeconomics, Basic Books, New York.

45 VON FURSTEINBURGH, G.M. \& B.G. MALKIEL (1977) "The Government and Capital Formation: A Survey of Recent Issues", Journal of Economic Literature, 15(3): 835-78.

46 WORLD BANK (1991). World Development Report, World Bank, Washington, DC. 